\title{
Analisis Perlakuan Akuntansi Zakat pada Lembaga Amil Zakat Baitul Maal Hidayatullah (BMH) Kabupaten Bondowoso
}

\author{
Imas Novita Mayangsari ${ }^{1 *}$, Dania Puspitasari ${ }^{2}$ \\ 1,2,3 Jurusan Akuntansi, Fakultas Ekonomi, Universitas Muhammadiyah Jember
}

\section{A R T I C L E I N F O \\ Article history: \\ Received 19 December 2018 \\ Received in revised form \\ 30 December 2018 \\ Accepted 01 January 2019 \\ Available online 15 \\ February 2019}

Kata Kunci:

Akuntansi, Lembaga Amil

Zakat, BMH Kabupaten

Bodowoso, Laporan

Keuangan, PSAK No 109

Keywords:

Accounting, Amil Zakat

Institution, BMH Bodowoso

District, Financial

Statement, PSAK No 109.

\begin{abstract}
A B S T R A K
Penelitian ini bertujuan untuk mengetahui bagaimana perlakuan akuntansi pengelolaan zakat pada Lembaga Amil Zakat $\mathrm{BMH}$ Kabupaten Bondowoso. BMH sebagai entitas ekonomi lembaga pengelolaan zakat membutuhkan suatu standart0akuntansi baku untuk pencatatan, pengukuran, dan penyajian laporan keuangannya. Metode penelitian yang digunakan adalah metode analisa deskriptif yaitu penerapan laporan keuangan yang meliputi analisis0terhadap pengakuan, pengukuran, pengungkapan dan pelaporanya. Hal ini dilakukan karena sampai saat ini belum terdapat standar akuntansi untuk lembaga amil zakat yang dikelola oleh lembaga tersebut. Hasil penelitian0ini dapat diungkapakan bahwa saat ini penerapan akuntansi di BMH Kabupaten Bondowoso masih belum menerapkan akuntansi zakat sesuai dengan yang ditetapkan oleh PSAK No.109 dalam hal pelaporan keuangannya.
\end{abstract}

\section{A B S T R A C T}

This study aims to find out how the management of zakat accounting at the Bondowoso Regency BMH Amil Zakat Institution. BMH as an economic entity managing zakat institutions requires a standard accounting standard for recording, measuring and presenting financial statements. The research method used is descriptive analysis method, namely the application of financial statements that include analysis of the recognition, measurement, disclosure and reporting. This is done because until now there has been no accounting standard for amil zakat institutions managed by the institution. The results of this study can be revealed that at present the application of accounting in BMH in Bondowoso Regency still has not applied zakat accounting in accordance with what is stipulated by PSAK No.109 in terms of financial reporting.

\footnotetext{
* Corresponding author.

E-mail addresses: imas.novita@yahoo.com (Imas Novita Mayangsari)
} 


\section{Pendahuluan}

Zakat merupakan salah satu rukun Islam yang berhubungan langsung dengan harta dan kondisi sosial seorang. Dalam istilah zakat berarti harta tertentu yang wajib dikeluarkan oleh orang beragama Islam dan diberikan kepada delapan golongan. Dengan mengeluarkan zakat, seseorang0akan baru dianggap sah bergabung dengan umat Islam dan diakui keislamannya, disamping syahadat, shalat dan puasa (Mu'is,02011).

Zakat0fitrah wajib bagi setiap muslim tanpa kecuali dan wajib mengeluarkan zakat pada bulan Ramadhan sebelum sholat Idul Fitri berupa makanan pokok sebesar 2,5 Kg. Tujuannya adalah membersihkan jiwa atau menyucikan diri dari dosa-dosanya. Zakat harta (mal) diwajibkan kepada muslim yang mempunyai harta dengan kepemilikan penuh. Dapat memberikan keuntungan (berkembang) dan telah melebihi batas minimal (nishab dan telah berlaku satu tahun (haul). Harta tersebut mencakup hasil perniagaan, pertanian, pertambangan, hasil laut, hasil ternak, harta temuan dan tambang, emas dan perak.

Pemerintah menyerahkan pengelolaan zakat mal dan fitrah kepada BAZNAS, Lembaga Amil Zakat (LAZ) dan Lembaga Amil Zakat, Infaq Sodaqoh (LAZIS) yang dibentuk oleh masyaraka, seperti LAZ Baitul Maal Hidayatullah (BMH) kabupaten Bondowoso. Dalam LAZ BMH kabupaten Bondowoso, dimana pelaporan keuangannya terdapat laporan perubahan dana yang sudah sesuai dengan PSAK N0.109, pada BMH juga terdapat neraca akan tetapi penyajian laporan keuangannyamasih tidak sesuai dengan PSAK No. 109 diantara laporan yang tidak sesuai seperti laporan posisi0keuangan (neraca) , laporan Perubahan Asset Kelolaan, dan laporan Arus Kas. Dalam penelitian ini penulis menemukan adanya masalah yang dapat dirumuskan sebagai berikut; bentuk kesesuain laporan keuangan BMH kabupaten Bondowoso dengan PSAK No.109 dan bentuk pelaporan keuangan BMH kabupaten Bondowoso yang sesuai dengan PSAK N0.109.Penelitian ini untuk bertujuan untuk mengetahui keseuaian laporan keuangan BMH kabupaten Bondowoso dengan PSAK No.109 serta untuk merekontruksi laporan keuangan BMH Kabupaten Bondowoso sesuai dengan PSAK No. 109.

\section{Metode}

Penelitian ini termasuk dalam kategori penelitian kualitatif dengan pendekatan analisis deskriptif, yaitu metode yang dilakukan dengan cara mengumpulkan, mempersiapkan, serta menganalisis data sehingga mendapat gambaran yang jelas mengenai masalah yang diteliti. Berdasarkan0pendekatan ini peneliti akan mengumpulkan serta menganalisis data berupa laporan keuangan organisasi tesebut yang nantinya akan memberikan gambaran jelas megenai penerapan akuntansi zakat pada Baitul Maal Hidayatullah (BMH) kabupaten Bondowoso.

Data penelitian pada dasarnya dapat dikelompokkan menjadi tiga jenis yaitu : 1. Data Subyek, 2. Data Fisik, 3. Data Dokumenter. Peneliti dalam melakukan penelitian ini menngunakan jenis data dokumenter. Data dokumenter adalah jenis data penelitian yang antara lain berupa; faktur, jurnal, surat-surat, notulen hasil rapat, memo, atau dalam bentuk laporan program. Penelitian ini dilakukan dengan cara mengamati jurnal yang telah tersedia di Baitul Maal Hidayatullah (BMH) sehingga diperoleh data secara detail tentang penerapan akuntansi zakat sesuai dengan PSAK 109.

Sumber data terdiri dari: 1) Data Primer, adalah data yang diperoleh secara langsung dari sumber asli (tidak melalui perantara). Data primer secara khusus dikumpulkan oleh peneliti untuk menjawab pertanyaan penelitian. Dimana data ini diperoleh melalui wawancara secara langsung dan observasi yaitu mengenai penerapan akuntansi zakat pada lembaga amil zakat (Indriantoro, 2016), 2) Data Sekunder, Indriatoro (2016) menyatakan bahwa data sekunder merupakan metode penelitian yang umumnya0menggunakan data ssekunder adalah peneliti arsip yang memuat kejadian0masa lalu.

Teknik pengumpulan data yang digunakan antara lain: a) Wawancara, dalam penelitian ini, peneliti melakukan0teknik pengumpulan data melalui wawancara dengan pihak pengelola kepala sekertariat BMH, bendahara sekertariat BMH serta karyawan-karyawan BMH yang terkait dalam memberikan informasi yang dibutuhkan. Menurut (Sugiyono, 2016) digunakan sebagai teknik pengumpulan data apabila peneliti ingin melakukan studi pendahuluan untuk menemukan permasalahan yang harus diteliti, b. Dokumen, merupakan catatan peristiwa0yang sudah berlalu. Dokumen bisa berbentuk tulisan, gambar atau karya-karya monumental dari seseorang (Sugiyono, 2016). Dalam penelitian ini, peneliti mencoba mendapatkan informasi mengenai permasalahan penerapan akuntansi zakat pada lembaga pengelolaan zakat yaitu BMH. Selain itu juga mengumpulkan data dan informasi melalui buku-buku, jurnal-jurnal, internet dan dengan melakukan penelitian terhadap dokumen dan laporan keuangan BMH yang berkaitan dengan penulisan skripsi ini. 
Pada penelitian ini terdapat beberapa tahap analisis yaitu sebagai berikut : a. Mengumpulkan data keuangan Baitul Maal Hidayatullah kabupaten Bondowoso, b. Mengidentifikasi data keuangan Baitul Maal Hidayatullah kabupaten Bondowoso, c. Mengklasifikasi data keuangan Baitul Maal Hidayatullah kabupaten Bondowoso, d. Merekontruksi Laporan Keuangan Baitul Maal Hidayatullah kabupaten Bondowoso berdasarkan PSAK 109.

\section{Hasil dan pembahasan}

Dalam analisis data peneliti berusaha menjelaskan dan memaparkan sesuai hasil dari pengamatan yang telah dilakukan. BMH Kabupaten Bondowoso tidak bisa lepas dari proses pencatatan setiap transaksi dari dana yang terkumpulkan dan penyaluran dana sesuai dengan ketentuan syariah yang berlaku. Dalam membuat laporan keuangannya, BMH Kabupaten Bondowoso belum mengacu pada PSAK 109.

\section{Mengumpulkan data Keuangan LembagaAmil Zakat BMH Kabupaten Bondowoso}

1. Proses Pengumpulan dana zakat

Zakat yang dikumpulkan oleh BMH Kabupaten Bondowoso berasal dari para muzakki yang menyalurkan zakat kepada $\mathrm{BMH}$, untuk besarnya infaq dan shadaqah yang diberikan tidak ada ketentuan yang diharuskan, pemberian tersebut tergantung pada pemberian sukarela para muzakki.

2. Proses Pendistribusian dana zakat oleh BMH Kabupaten Bondowoso

Pendistribusian zakat pada BMH Bondowoso dilakukan dengan menyerahkan dana zakat,infaq dan shadaqah kepada 8 kelompok ashnaf, serta didistribusikan dalam pelaksanaan pembangunan sekolah.

\section{Mengidentifikasi Data Keuangan BMH Kabupaten Bondowoso}

Penyajian Laporan Keuangan yang dibuat oleh BMH Kabupaten Bondowoso adalah Laporan zakat profesi dari para muzakki, laporan infaq dan shadaqah dari unit pengumpulan zakat dan instansi yang terkait dari neraca keuangan. Laporan ini berisi informasi mengenai jumlah dana zakat yang terdapat pada LAZ BMH kabupaten Bondowoso. Manajemen lembaga zakat secara berkala harus menerbitkan laporan keuangannya. Laporan ini menjadi sangat penting dalam rangka meningkatkan kepercayaan para muzakki. Berikut laporan keuanga zakat, infak/sedekah, dan amil pada BMH kabupaten Bondowoso

Tabel 1 Laporan Keuangan Zakat Lembaga Amil Zakat BMH Kab. Bondowoso Per 31 Desember 2017

\begin{tabular}{llll}
\hline NO & BULAN & PEMASUKAN & PENGELUARAN \\
\hline 1 & JANUARI & 1.931 .500 & 926.000 \\
2 & FEBRUARI & 4.653 .000 & 4.000 .000 \\
3 & MARET & 2.541 .000 & 1.268 .000 \\
4 & APRIL & 1.886 .000 & 1.151 .600 \\
5 & MEI & 30.054 .000 & 8.122 .154 \\
6 & JUNI & 10.003 .000 & 6.298 .342 \\
7 & JULI & 2.489 .500 & 4.678 .710 \\
8 & AGUSTUS & 4.476 .500 & 964.000 \\
9 & SEPTEMBER & 2.252 .000 & 220.500 \\
10 & OKTOBER & 2.765 .500 & 1.312 .500 \\
11 & NOVEMBER & 3.176 .500 & 1.224 .500 \\
12 & DESEMBER & 2.888 .000 & 1.790 .500 \\
& Jumlah & 51.389 .500 & 31.956 .806 \\
\hline
\end{tabular}

Tabel 2. Laporan Keuangan Infak Lembaga Amil Zakat BMH Kab. Bondowoso Per 31 Desember 2017

\begin{tabular}{llll}
\hline NO & BULAN & PEMASUKAN & PENGELUARAN \\
\hline 1 & JANUARI & 31.555 .344 & 33.268 .174 \\
2 & FEBRUARI & 32.448 .349 & 32.175 .447 \\
3 & MARET & 31.197 .890 & 27.391 .510 \\
4 & APRIL & 31.126 .785 & 27.609 .000 \\
5 & MEI & 50.269 .935 & 64.767 .096 \\
6 & JUNI & 19.890 .501 & 22.683 .908 \\
7 & JULI & 30.077 .107 & 26.513 .290 \\
8 & AGUSTUS & 86.388 .419 & 83.268 .500 \\
9 & SEPTEMBER & 33.344 .216 & 34.093 .309 \\
\hline
\end{tabular}




\begin{tabular}{llll}
\hline 10 & OKTOBER & 32.075 .878 & 32.407 .000 \\
11 & NOVEMBER & 31.026 .926 & 30.894 .384 \\
12 & DESEMBER & 31.981 .192 & 32.507 .500 \\
& JUMLAH & $\mathbf{4 4 1 . 3 8 2 . 5 4 4}$ & $\mathbf{4 4 7 . 5 7 9 . 1 1 8}$ \\
\hline
\end{tabular}

Tabel 3. Laporan Keuangan Amil Lembaga Amil Zakat BMH Kab. Bondowoso Per 31 Desember 2017

\begin{tabular}{llll}
\hline NO & BULAN & PEMASUKAN & PENGELUARAN \\
\hline 1 & JANUARI & 10.176 .000 & $13.450 .344,38$ \\
2 & FEBRUARI & 11.680 .000 & 14.097 .249 \\
3 & MARET & 11.518 .000 & 14.897 .655 \\
4 & APRIL & 10.401 .600 & 13.833 .961 \\
5 & MEI & 21.477 .905 & 20.466 .486 \\
6 & JUNI & 7.404 .092 & 7.177 .250 \\
7 & JULI & 12.428 .710 & 12.947 .000 \\
8 & AGUSTUS & 13.964 .000 & 16.922 .500 \\
9 & SEPTEMBER & 12.220 .500 & 12.793 .070 \\
10 & OKTOBER & 14.312 .500 & 13.785 .205 \\
11 & NOVEMBER & 14.224 .500 & 15.224 .500 \\
12 & DESEMBER & 15.790 .500 & 15.555 .859 \\
& JUMLAH & $\mathbf{1 5 5 . 5 9 8 . 3 0 6}$ & $\mathbf{1 7 1 . 2 0 1 . 0 7 9}$ \\
\hline
\end{tabular}

Untuk penyajian dana zakat, infaq, shadaqah, dan dana amil BMH Kabupaten Bondowoso hanya membuat Laporan Posisi Keuangan (Neraca), untuk bentuk transparansi BMH kabuapaten Bondowoso terhadap muzakki.

Neraca Keuangan

Tabel 4. Neraca BMH kabupaten Bondowoso

\section{LAPORAN POSISI KEUANGAN \\ Periode 31 Desember 2017 \\ (Dalam Satuan Rupiah)}

ASET

Aset Lancar

$\begin{array}{lr}\text { Kas dan Setara Kas } & \text { Rp 64. 714.847 } \\ \text { Jumlah Aset Lancar } & \text { Rp 64.714.847 }\end{array}$

\section{Kewajiban Dan Saldo \\ Dana}

Kewajiban

Saldo Dana

JUMLAH KEWAJIBAN

DAN SALDO DANA
Zakat
Infak/Sedekah
Amil
Jumlah Saldo Dana

Rp 19.792 .694

(Rp 6.196.574)

Rp 51.118.727

Rp 64.714.847

\section{Rp 64.714.847}

Sumber Data BMH kabupaten Bondowoso

Laporan di atas merupakan laporan posisi keuangan BMH Kabupaten Bondowoso yang diterbitkan setiap tahunnya. Dan neraca keuangan yang di buat BAZNAS Kabupaten Bondowoso sudah mengacu pada PSAK 109, akan tetapi ada beberapa komponen yang msih belum sesuai dengan PSAK 109 yaitu tidak terdapat instrumen keuangan, dan penyusunan kewajibannya masih tidak sesuai dengan PSAK No.109. 


\section{Merekontruksi Laporan Keuangan LAZ Baitul Maal Hidayatullah Kabupaten Bondowoso berdasarkan PSAK No. 109}

Transaksi yang dilakukan oleh BMH Kab. Bondowoso hanya mencatat transaksi dalam laporan perubahan dana, sedangkan untuk keuangan lain seperti neraca dan laporan arus kas masih belum ada. Maka peneliti membantu merancang neraca dan laporan arus kas sesusi dengan PSAK No.109 sebagai berikut :

Tabel 5. Neraca (Laporan Posisi Keuangan) Baitul Maal Hiayatullah (BMH) Kabupaten Bondowoso Per 31 Desember 2017

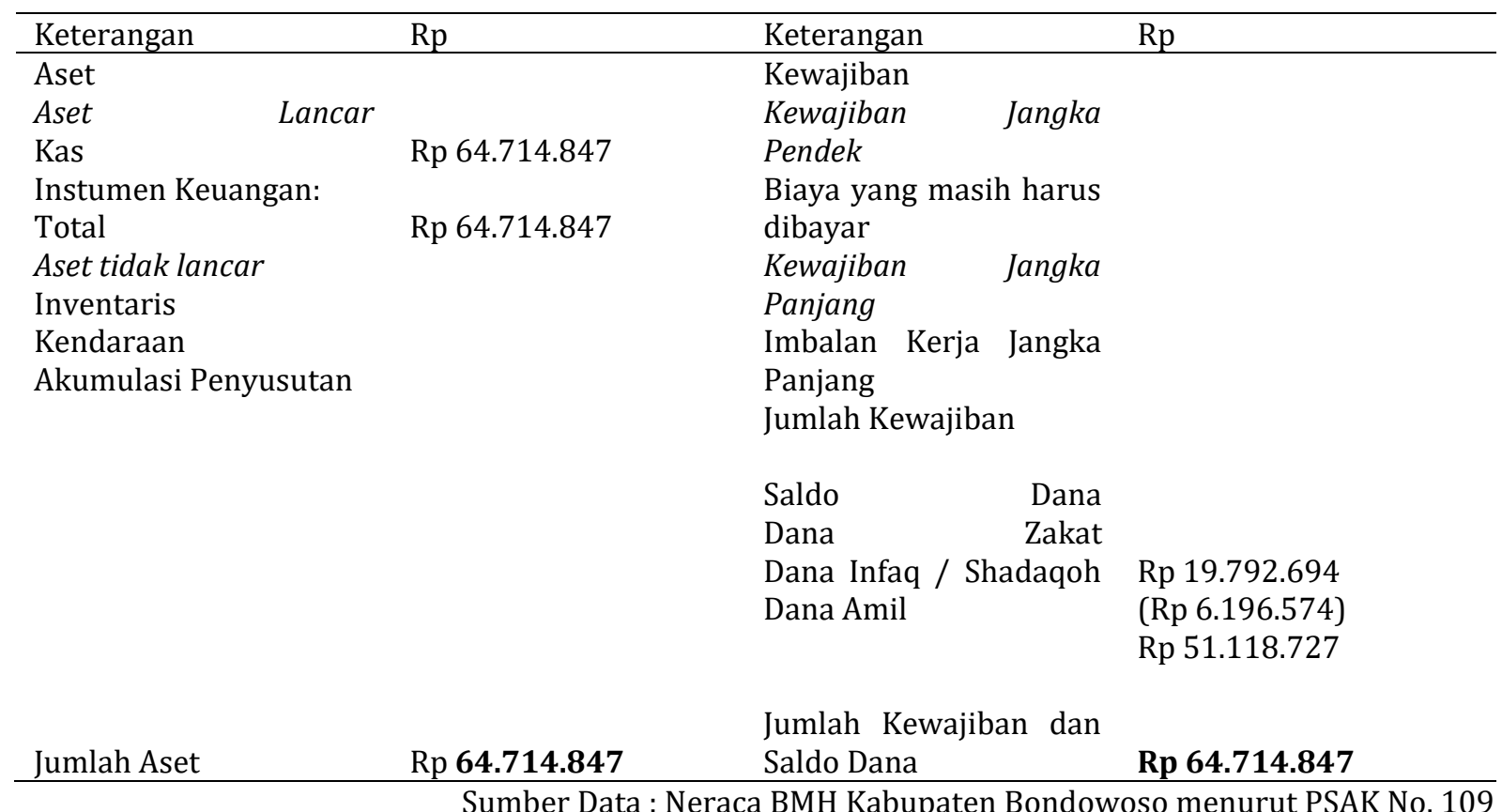

Neraca keuangan yang dibuat BAZNAS Kabupaten Bondowoso sudah mengacu pada PSAK No. 109. Penulisan Aktiva Lancar, Aktiva Tetap, Total Aktiva, Kewajiban Lancar, Kekayaan Bersih, Total Modal,, Total Kewajiban dan Modal yang sebelumnya digunakan pada laporan posisi keuangan telah disesuaikan dengan ketentuan PSAK No.109

1. Berikut ini adalah format laporan perubahan dana :

Tabel 6. Laporan Perubahan Dana Baitul Maal Hidayatullah (BMH) Kabupaten Bondowoso Per 31 Desember 2017

\begin{tabular}{|c|c|}
\hline \multirow{2}{*}{\multicolumn{2}{|c|}{$\begin{array}{l}\text { Keterangan } \\
\text { DANA ZAKAT }\end{array}$}} \\
\hline & \\
\hline Penerimaan & \\
\hline Muzakki entitas & - \\
\hline Muzakki individual & Rp 51.389.500 \\
\hline Hasil penempatan & \\
\hline Jumlah penerimaan dana zakat & Rp 51.389.500 \\
\hline Bagian amil atas penerimaan dana zakat & \\
\hline $\begin{array}{l}\text { Jumlah penerimaan dana zakat setelah bagian amil } \\
\text { Penyaluran }\end{array}$ & - \\
\hline Faqir-miskin & Rp 10.608.500 \\
\hline Riqab & - \\
\hline Gharim & - \\
\hline Muallaf & - \\
\hline Sabilillah & Rp 8.750.000 \\
\hline Ibnu Sabil & - \\
\hline Amil & Rp 12.598.306 \\
\hline
\end{tabular}




\begin{tabular}{ll}
\hline Jumlah penyaluran dana zakat & $\mathrm{Rp} 31.596 .806$ \\
Surplus (defisit) & $\mathrm{Rp} 19.792 .694$ \\
DANA INFAQ/SEDEKAH & \\
Penerimaan & \\
Infaq/sedekah terikat atau muqayaddah & $\mathrm{Rp} 129.207 .000$ \\
Infaq/sedekah tidak terikat atau mutlaqah & $\mathrm{Rp} 312.175 .544$ \\
Jumlah penerimaan dana infaq/sedekah & $\mathrm{Rp} 441.382 .544$ \\
& \\
Penyaluran & \\
Infaq/sedekah terikat atau muqayaddah & $\mathrm{Rp} 139.708 .300$ \\
Infaq/sedekah tidak terikat atau mutlaqah & $\mathrm{Rp} 307.870 .818$ \\
Alokasi pemanfaatan aset kelolaan & - \\
Jumlah penyaluran dana infaq/sedekah & $\mathrm{Rp} 447.579 .118$ \\
Surplus(defisit) & $(\mathrm{Rp} 6.196 .574)$ \\
DANA AMIL & \\
Penerimaan & \\
Bagian amil dari dana zakat & $\mathrm{Rp} 12.598 .306$ \\
Bagian amil dari dana infaq/sedekah & $\mathrm{Rp} 143.000 .000$ \\
Penerimaan lainnya & - \\
Jumlah penerimaan dana amil & $\mathrm{Rp} 155.598 .306$ \\
Penggunaan & \\
Beban pegawai & $\mathrm{Rp} 66.364 .500$ \\
Beban rumah tangga & $\mathrm{Rp} .37 .793 .900$ \\
Beban umum dan administrasi lainnya & $\mathrm{Rp} 321.779$ \\
Jumlah penggunaan dana amil & $\mathrm{Rp} 104.479 .579$ \\
Surplus (defisit) & $\mathrm{Rp} 51.118 .727$ \\
Dana Lain-Lain & - \\
Jumlah saldo dana zakat, dana infak/sedekah, dan dana & $\mathrm{Rp}$ 64.714.847 \\
\hline anil &
\end{tabular}
amil

Sumber Data: Laporan Perubahan Dana BMH Kabupaten Bondowoso menurut PSAK No.109

Laporan perubahan dana yang dibuat oleh Baitul Maal Hidayatullah (BMH) kabupaten Bondowoso sudah mengacu pada PSAK No.109

Berikut adalah format laporan perubahan aset kelolaan

Tabel 7. Laporan Perubahan Aset Kelolaan Baitul Maal Hidayatullah (BMH) Kabupaten Bondowoso Per 31 Desember 2017

\begin{tabular}{lllllll}
\hline & $\begin{array}{l}\text { Saldo } \\
\text { awal }\end{array}$ & $\begin{array}{l}\text { Penam- } \\
\text { bahan }\end{array}$ & $\begin{array}{l}\text { Pengu- } \\
\text { rangan }\end{array}$ & $\begin{array}{l}\text { Penyi- } \\
\text { sihan }\end{array}$ & $\begin{array}{l}\text { Akumulasi } \\
\text { penyusutan }\end{array}$ & Saldo akhir \\
\hline $\begin{array}{l}\text { Dana infak/sedekah - aset } \\
\text { kelolaan lancar }\end{array}$ & - & - & $(-)$ & $(-)$ & - & - \\
$\begin{array}{l}\text { Dana infak/sedekah - aset } \\
\text { kelolaan tidak lancer }\end{array}$ & - & - & $(-)$ & - & $(-)$ & - \\
\hline
\end{tabular}

Sumber Data: Laporan Perubahan Aset Kelolaan BMH kabupaten Bondowoso menurut PSAK No. 109

Baitul Maal Hidayatullah (BMH) kabupaten Bondowoso belum membuat laporan perubahan aset kelolaan, karena dana yang diperoleh masih terbatas dan tidak terdapat aset kelolaan yang dilakukan oleh BMH kabupaten Bondowoso

Berikut ini adalah format laporan arus kas : 
Tabel 8. Laporan Arus Kas Baitul Maal Hidayatullah (BMH) Kabupaten Bondowoso Per 31 Desember 2017

\begin{tabular}{|c|c|}
\hline ARUS KAS DARI AKTIVITAS OPERASI & \\
\hline Penerimaan dana zakat & Rp 51.389.500 \\
\hline Penerimaan dana infaq/sedekah & Rp 441.382.544 \\
\hline Penerimaan dana kemanusiaan & 0 \\
\hline Penerimaan Dana Lain-lain & Rp 30.130.421 \\
\hline Penerimaan bunga dan jasa giro bank konvensional & 0 \\
\hline Penyaluran kepada fakir-miskin & (Rp 10.608.500) \\
\hline Penyaluran Infaq/sedekah terikat atau muqayaddah & $(\mathrm{Rp} 139.708 .300)$ \\
\hline Penyaluran Infaq/sedekah tidak terikat atau mutlaqah & (Rp 307.870.818) \\
\hline Penyaluran bantuan ke daerah & \\
\hline Penyaluran piutang pendidikan & \\
\hline Arus kas bersih dari aktivitas operasi & \\
\hline
\end{tabular}

Merupakan catatan yang menjelaskan mengenai gambaran umum suatu organisasi, ikhtisar kebijakan akuntansi, serta penjelasan tentang pos-pos laporan keuangan dan informasi lainnya yang bersangkutan dengan objek penelitian. Dilihat dari rekonstruksi laporan keuangan BMH Kabupaten Bondowoso yang dibuat belum mengacu pada PSAK No. 109.

Dengan laporan keuangan yang telah ditampilkan dan dipublikasi seperti ini memang cukup mudah dipahami oleh masyarakat umum (donator), karena sudah cukup transparan dalam melaporkan keuangan kepada masyarakat. Laporan keuangan BMH Kabupaten Bondowoso diterbitkan dalam periode setiap bulan dan tahunan. Laporan keuangan setiap bulan ditujukan untuk pihak internal dan untuk masyarakat umum (donatur) sebagai bentuk akuntabilitas.Laporan Keuangan yang disajikan oleh BMH di audit oleh Auditor Internal atau Badan Pengaw as BMH dan belum di audit oleh Kantor Akuntan Publik. Sebagai bentuk akuntanbilitas BMH,. Pembuat laporan keuangan BMH adalah sebagai bentuk pertanggung jawabannya pihak BMH kepada para muzakki.

\section{Simpulan dan saran}

Berdasarkan dari hasil penelitian dan pembahasan yang telah dibahas dalam bab sebelumnya, dihasilkan beberapa kesimpulan berikut, antara lain: 1) Laporan keuangan yang terdapat pada Baitul Maal Hidayatullah (BMH) kabupaten Bondowoso masih belum sesuai dengan PSAK No.109, laporan keuangan yang dibuat oleh BMH hanya neraca dan laporan perubahan dana, 2) Peneliti melakukan pengumpulan data, mengidentifikasi data dan merekontruksi data laporan keuangan BMH kabupaten Bondowoso. Peneliti melakukan rekontruksi laporan keungan BMH menurut PSAK No.109

Berdasarkan hasil penelitian, maka dapat disarankan hal-hal sebagai berikut: 1) BMH Kabupaten Bondowoso harus membuat laporan keuangan sesuai dengan PSAK No.109, 2) Diharapkan peneliti selanjutnya bisa menggunakan objek penelitian yang lebih luas dengan waktu yang efektif dan efisien, sehingga dapat lebih. .

\section{Daftar Rujukan}

Al-Qur’an. Terjemahan Departemen Agama. Jakarta: Departemen Agama.

Badan Penerbit Universitas Muhammadiyah Jember. 2015. Pedoman Penulisan Skripsi; Fakultas Ekonomi. UM Jember.

Andi.2013 Analisis0Penerapan Akuntansi Zakat, Infak Dan Sedekah Pada LAZ Dompet Dhuafa Cabang Makassar. Skripsi, Fakultas Ekonomi Dan Bisnis Universitas Hasanuddin.

Exposure Draft PSAK no. 109. Akuntnasi Zakat, Infaq, dan Shodaqoh

Huda, Nurul, dan Novarini. 2015. Zakat Perspektif Mikro-Makro. Edisi Pertama, Jakarta, Prenadamedia Group. 
Ikatan Akuntansi Indonesia, PSAK NO. 109, Dewan Standar Akuntansi Keuangan Ikatan Akuntan Indonesia, 2008

Ikatan Akuntansi Indonesia IAI.2016. Akuntansi Zakat dan Infak/Sedekah. Jakarta, IAI Indonesia.

Indriantoro, Nur. dan Bambang Supomo. 2016. Metodologi Penelitian Bisnis. Edisi Pertama, Jilid VII, Yogyakarta: BPFE

Lembaga Amil Zakat (LAZ). Baitul Maal0Hidayatullah (BMH). Kabupaten Bondowoso

Mahmudi, Sistem Akuntansi Organisasi Pengelola Zakat, Yogyakarta: PPPEI Press, 2009.

Mu'is, Fahrur.2011. Zakat A-Z Panduan0Mudah, Lengkap, dan Praktis tentang

Zakat. Solo: Tinta Medina.

Republika.co.id. Jakarta. 2017. BMH Himpun Dana Ziswaf Rp.138 Miliar. Diaskes melalui

hhtp:/2016,\%20Baitul\%20Maal\%20Hidayatullah\%20Himpun\%20Dana\%20Ziswaf\%20Rp\%20138\%20 Miliar\%20_\%20Republika\%200nline.htm pada tanggal 16 Maret 2018, Jam 18.41 WIB

Republik Indonesia. 2011. Undang-Undang Nomor 23 Tahun 2011 tentang pengelolaan zakat. Lembaran Negara Republik Indonesia Nomor 115, Sekretariat Negara Jakarta

Ritonga Pandapotan. 2017 Analisis Akuntansi Zakat Berdasarkan PSAK No 109 Pada Badab Amil Zakat Nasional ( BAZNAS ) Sumatera Utara. Jurnal, Fakultas Ekonomi Universitas Muhammadiyah Sumatera Utara.

Sugiyono. 2016. Metode Penelitian Kuantitatif, Kualitatif, dan R\&D. PT Bandung, Alfabeta.

Umah. 2011 Penerapan Akuntansi Zakat Pada Lembaga Amil Zakat Cabang Semarang. Skripsi. Fakultas Ekonomi Syari'ah IAIN Walisongo Semarang.

Undang-undang Republik Indonesia No. 38 Tahun 1999 tentang Pengelolaan Zakat, http://www.tempointeraktif.com. 